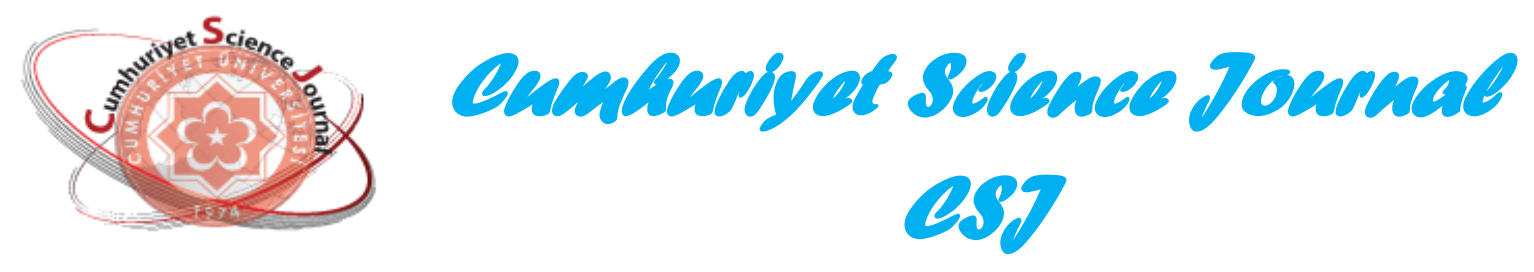

e-ISSN: 2587-246X

ISSN: 2587-2680

Cumhuriyet Sci. J., Vol.39-3(2018) 728-733

\title{
Growth Temperature Dependency of High Al Content AlGaN Epilayers on $\mathrm{AlN} / \mathrm{Al}_{2} \mathrm{O}_{3}$ Templates
}

\author{
Ilkay DEMIR \\ Cumhuriyet University, Nanophotonics Research and Application Center, Department of Nanotechnology \\ Engineering, Sivas, TURKEY
}

Received: 14.08.2018; Accepted: 04.09.2018

http://dx.doi.org/10.17776/csj.453476

\begin{abstract}
In this work, MOVPE (Metalorganic Vapor Phase Epitaxy) growth and characterization studies of high $\mathrm{Al}$ content $\mathrm{AlGaN}$ epilayers are reported. We utilize high resolution X-ray diffraction (HRXRD) and atomic force microscope (AFM) techniques to analyze the crystalline quality and surface morphology of AlGaN epilayers. The role of the growth temperature of AlGaN epilayers on the structural quality and the surface morphology was investigated. Growth and measurement results show that single phase AlGaN epilayers were grown on $\mathrm{AlN} / \mathrm{Al}_{2} \mathrm{O}_{3}$ template. It is concluded that the increasing growth temperature increases the $\mathrm{Al}$ content of AlGaN epilayers which enable to control the alloy concentration of AlGaN. Furthermore, the increasing $\mathrm{Al}$ content in AlGaN epilayers leads to the smooth surface which indicates that the decreasing number of dislocation density.
\end{abstract}

Keywords: AlGaN, MOVPE, AlN, Al2O3, X-ray diffraction, Atomic force microscope.

\section{$\mathrm{AIN} / \mathrm{Al}_{2} \mathrm{O}_{3}$ Şablonlar Üzerindeki Yüksek Al İçerikli AIGaN epi- Tabakaların Büyütme Sıcaklığı Bağımlılığı}

\footnotetext{
Özet. Bu çalışmada, yüksek Al içerikli AlGaN epi-tabakaların MOVPE (Metalorganik Buhar Fazı Epitaksi) büyütmesi ve karakterizasyon çalışmaları rapor edilmiştir. AlGaN epi-tabakaların kristal kalitesi ve yüzey morfolojisi analizi için yükssek çözünürlüklü X-ışını kırınımı (HRXRD) ve atomik kuvvet mikroskobu teknikleri kullanılmıştır. Büyütme sıcaklığının AlGaN epi-tabakalarının yapısal kalitesi ve yüzey morfolojisi üzerindeki rolü incelenmiştir. Büyütme ve ölçüm sonuçları $\mathrm{AlN} / \mathrm{Al}_{2} \mathrm{O}_{3}$ şablonu üzerine tek fazda $\mathrm{AlGaN}$ epi-tabakaların büyütüldüğünü göstermektedir. Artan büyütme sıcaklığının AlGaN'in Al içeriğini arttırdığı ve bunun AlGaN alaşım konsantrasyonunu kontrol etmeye olanak sağladığı sonucuna varılmıştır. Ayrıca, AlGaN epi-tabakalarındaki Al içeriğinin artışı pürüzsüz yüzeye yol açar ki bu dislokasyon yoğunluğunun azaldığını belirtir.
}

Anahtar Kelimeler: AlGaN, MOVPE, AlN, A12O3, X-1şını kırınımı, Atomik kuvvet mikroskobu

\section{INTRODUCTION}

III-Nitride semiconductor compounds consist of the combination of group III elements such as Ga (gallium), In (indium), Al (aluminum) with $\mathrm{N}$ (nitrogen). They can be used widely in electronics [1-3] and optoelectronics [4-6] applications. In recent years new application areas of III-Nitride semiconductors have emerged especially for the UV (ultraviolet) radiation of the electromagnetic spectrum because of their superior advantages such as wide and direct band gap, high thermal stability, high breakdown field etc. [5]. The market forecast for UV-LEDs (light emitting diodes) is increasing from $\$ 90$ million in the year 2014 to $\$ 800$ million by the year 2020 due to the increasing demands in epoxy curing, water purification, food or medical sterilization, and many new emerging applications[5]. UV radiation can be divided into three regions, comprising the UV-A region (320- 
$400 \mathrm{~nm})$, the UV-B region $(280-320 \mathrm{~nm})$, and the UV-C region (100-280 nm) [7]. Due to the eminent optoelectronic properties in the UV region and especially in the deep ultraviolet (DUV) region of the spectrum, AlGaN material has received considerable attention recently. AlGaN-based UVLEDs have many advantages such as small size, compact structure, low power consumption-low operating voltage, long lifetimes, high efficiency etc. compared to the mercury-based traditional UV light sources. AlGaN is a ternary alloy of direct bandgap of AlN and GaN compounds. Native AlN substrates can be considered the best material for DUV device applications but still AlN substrates are very expensive and they are still limited to very small sizes. There are many studies have been conducted to increase AlGaN and AlN quality on different foreign substrates such as silicon [8-11] but the most used one is sapphire since sapphire's transparency in DUV spectral region, low cost, wide availability in a large diameter, and stability at high temperatures. Generally, AlN buffer layer on sapphire substrate is used as a template for DUV applications because of low lattice mismatch between high $\mathrm{Al}$ content AlGaN and AlN. There are many difficulties to grow AlN and high $\mathrm{Al}$ content AlGaN alloy on sapphire substrate or on AlN/sapphire templates. There is a large lattice mismatch between AlN and sapphire which leads to a high dislocation density. Also, large thermal expansion coefficient difference between sapphire and AlN causes large strain and there occurs crack during cool down from the growth temperature. Additionally, there is an obstacle to grow AlN or high $\mathrm{Al}$ content of AlGaN alloy because of low surface migration mobility of $\mathrm{Al}$ atoms and parasitic pre-reactions between TMAl (trimethylaluminum) and NH3 (ammonia) results in dislocation density in $\mathrm{AlGaN}$ epilayers.

In this work, epitaxial AlGaN epilayers were grown by MOVPE (metalorganic vapor phase epitaxy) on AlN/sapphire templates with different growth temperatures. Structural quality and surface morphology of these structures were conducted by high resolution X-ray diffraction (HRXRD) and atomic force microscopy (AFM).

\section{EXPERIMENTAL}

AlGaN epitaxial layers were grown on c-plane sapphire substrates by using an Aixtron 200/4 RF$\mathrm{S}$ low pressure, horizontal-flow MOVPE system with radio frequency (RF) heating. TMAl, trimethylgallium (TMGa) and $\mathrm{NH}_{3}$ were used as precursors of $\mathrm{Al}, \mathrm{Ga}$, and $\mathrm{N}$ sources, respectively. Trimethylindium (TMIn) was used as a surfactant to increase the surface mobility of aluminum adatoms as studied previously [12-13]. Before start the growth, sapphire substrates were thermally desorbed at $1150{ }^{\circ} \mathrm{C}$ for 10 minutes under $\mathrm{H}_{2}$ ambient to remove surface contamination and adsorbed water. A mixture of $\mathrm{H}_{2}$ and $\mathrm{N}_{2}$ was used as the carrier gas for the subsequent growth. A 20 $\mathrm{nm}$ thick low temperature AlN nucleation layer then $300 \mathrm{~nm}$ thick high temperature PALE (pulsed atomic layer epitaxy) AlN were grown on sapphire substrate. Growth details of this AlN/sapphire template were explained in detail in previous studies $[8,14]$. Three (A, B and C) different AlGaN epilayers were grown on optimized AlN/sapphire template at 1020,1180 and $1220{ }^{\circ} \mathrm{C}$, respectively.

\section{RESULTS AND DISCUSSION}

The crystalline quality of all AlGaN/AlN/sapphire structures has been investigated by measuring $2 \theta / \omega$ symmetric (0002) plane reflections via HRXRD (Figure 1). It is seen from the Figure 1 that there are three peaks belong to AlGaN/AlN/sapphire structures for each sample. The sharpest and the highest peak belongs to sapphire substrate. The middle one and the left one belong to AIN template and the AlGaN epilayers, respectively. HRXRD scans and analyses from the Figure 1 show that there are no excess peaks detected which indicates that other phases of AlGaN epilayers were not formed. Additionally, inset of Figure 1 shows that the AlN peak intensity increases with the increase of AlGaN growth temperature. Even the AlN quality is independent of the AlGaN epilayer growth temperature and the template is same for all growths it is thought that the increasing behavior of this peak is because of the deflection of $\mathrm{x}$-ray beam from the AlGaN epilayers and it affected the AlN peak intensity. 


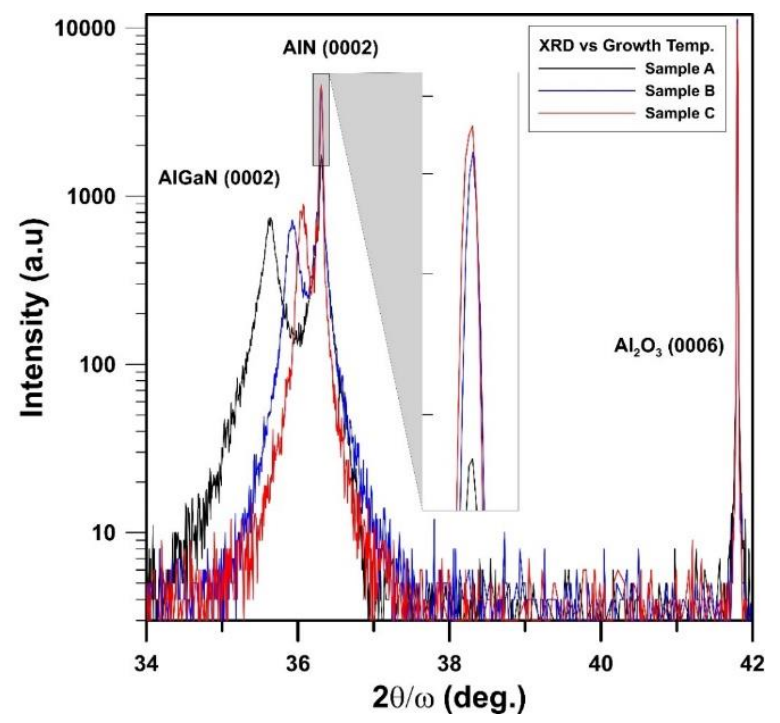

Figure 1. 20/ $\omega$ HRXRD of Sample A (black), Sample B (blue) and Sample C (red). The inset shows the magnified AlN (0002) diffraction peaks of samples.

Figure 2 shows $\mathrm{Al}$ content and HRXRD peak FWHM (full width half maximum) of AlGaN epilayers variation with the increase of growth temperature. It is seen from the figure 2 that sample $\mathrm{A}, \mathrm{B}$ and $\mathrm{C}$ have $54.8 \%, 74.5 \%$ and $83.9 \% \mathrm{Al}$ content in $\mathrm{AlGaN}$ epilayers, respectively. It means that $\mathrm{Al}$ incorporation was increased linearly by the increase of growth temperature. There may be two factors which increase the $\mathrm{Al}$ content in $\mathrm{AlGaN}$ epilayers; the first one is the $\mathrm{Al}$ incorporation efficiency increases with the increase of growth temperature. The second one is considered to be due to the Ga suppression inability at higher growth temperatures. It can be concluded that it is possible to control the $\mathrm{Al}$ content in AlGaN epilayers by controlling the growth temperature. Figure 2 also shows the dependence of AlGaN XRD peak FWHM for (0002) reflection with the increase of growth temperature. It is 746 arcsec for sample A, 650 arcsec for sample B and 496 arcsec for sample C. It seems that the crystal quality of $\mathrm{AlGaN}$ epilayers improves as the $\mathrm{Al}$ content increases with the increase of growth temperature. It is considered that this is due to a decreasing lattice constant difference between AlGaN and AlN leading to decreasing of misfit dislocations at elevated temperatures because of the increased $\mathrm{Al}$ content.
It is also demonstrated in the literature that $\mathrm{AlGaN}$ crystal quality deteriorates as the AlN content decreases to approximately 0.40 and then improves as the AlN content decreases further because of the small lattice constant difference between two successive layers. At an AlN content of 0.40 and above, the growth mode changed to the layer by layer mode [two-dimensional (2D) growth mode]. Because the difference in the lattice constants between the AlGaN layer and the AlN underlying layer decreases with increasing AlN mole fraction, the density of misfit dislocations was reduced; thus, the FWHM value decreased as the AIN content was increased from 0.548 to 0.839 [15].

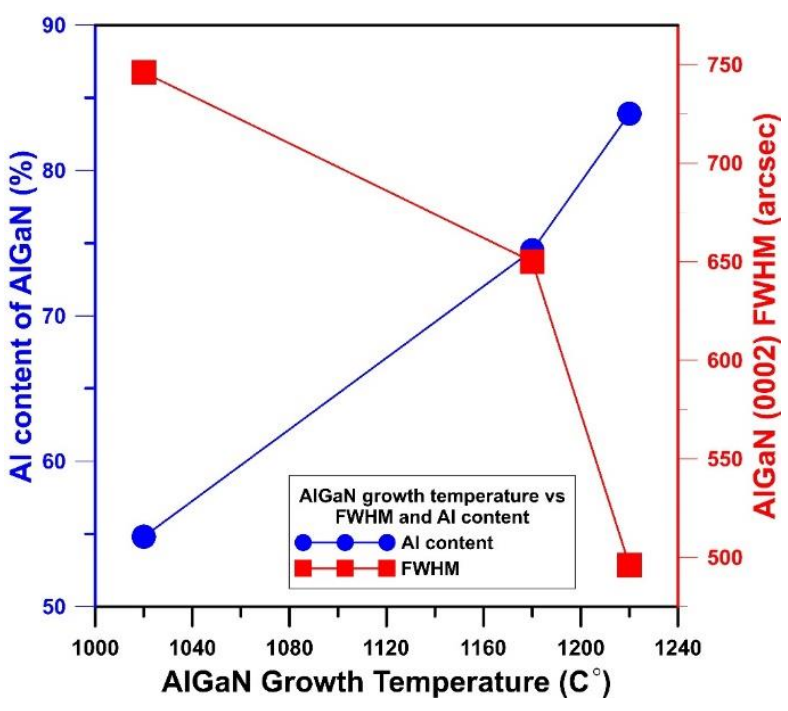

Figure 2. Al content (blue) and HRXRD peak FWHM (red) of AlGaN epilayers versus growth temperature.

In order to analyze the surface morphology of AlGaN epilayers, $5 \times 5 \mu \mathrm{m}^{2}$ and $1 \mathrm{x} 1 \mu \mathrm{m}^{2}$ regions were scanned by AFM at tapping mode. Figure 3 shows $5 \times 5 \mathrm{~m}^{2}$ scan area images of $\mathrm{AlGaN}$ epilayer surfaces for all samples. Figure 3 demonstrates that lower growth temperature (1020 ${ }^{\circ} \mathrm{C}$ ) of AlGaN (Sample A) results with the bumpy surface and for the higher growth temperatures (Sample B $\left(1180{ }^{\circ} \mathrm{C}\right)$ and $\mathrm{C}\left(1220^{\circ} \mathrm{C}\right)$ large area surfaces look smoother. The bumpy surface actually occurs because of the spiral type of AlGaN growths [16]. Spiral growth can be grouped into two different types: A and B. Type A occurs around a large dislocation core (e.g., a nanopit). In contrast, the more common type B is composed of 
two interlacing components rotated by $180^{\circ}$ [16]. We have both kinds of spiral growth types for the lower growth temperature (sample A). With the decreasing of $\mathrm{Al}$ content in $\mathrm{AlGaN}$ epilayer, the strain increases, leading to more defects [17]. For the increasing growth temperatures (increased $\mathrm{Al}$ content in $\mathrm{AlGaN}$ ) it seems that $\mathrm{AlGaN}$ surfaces don't have spiral growth mode anymore which indicates the decreasing number of density of dislocations.

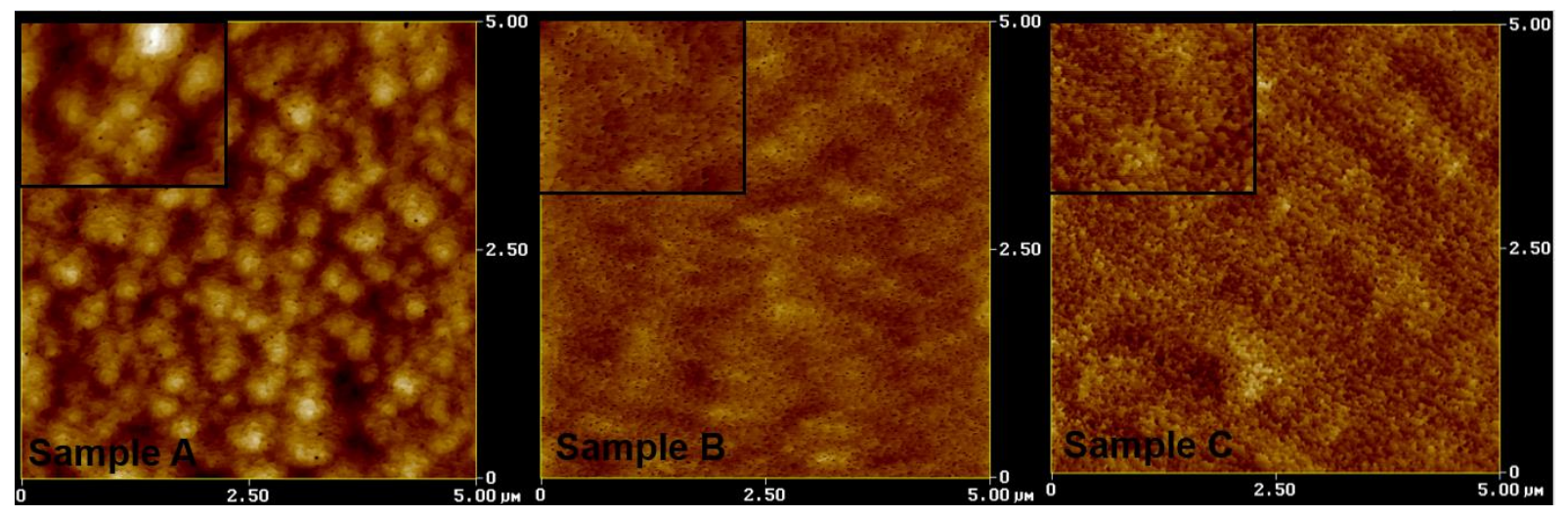

Figure 3. $5 \times 5 \mu \mathrm{m}^{2}$ scan area AFM images of AlGaN epilayer surfaces for sample A, B and C. Upper left images show the magnified images of the region of interest.

When one checks the small area $\left(1 \mathrm{x} 1 \mu \mathrm{m}^{2}\right)$ AFM images of samples it seems that there are many dark spots on the surface. These dark spots cannot be distinguished clearly on the surface of sample A because of the rough surface. These dark spots highlight the non-radiative behavior of the dislocations in $\mathrm{AlGaN}$ [18]. Based on their different sizes dark spots can be classified as pure- edge type (small), pure-screw type (large) and mixed-type (middle) threading dislocations [19]. Except for the dark spots atomic steps on the AlGaN surfaces can be clearly seen which indicate the smooth surface morphology. It is also important to note that the average root mean square roughness (rms) of sample surfaces to realize the effect of growth temperature quantitatively.

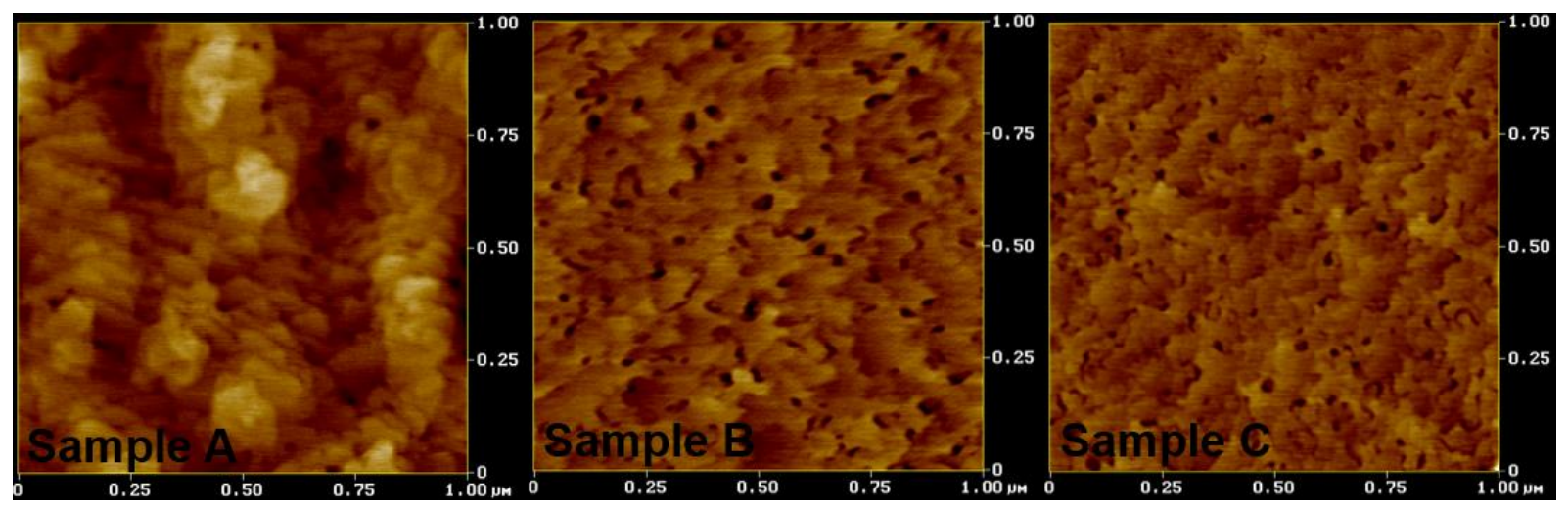

Figure 4. $1 \mathrm{x} 1 \mu \mathrm{m}^{2}$ scan area AFM images of AlGaN epilayer surfaces for sample A, B, and C.

Figure 5 shows the rms values variation of $5 \times 5 \mu \mathrm{m}^{2}$ (red square) and $1 \times 1 \mu \mathrm{m}^{2}$ (blue circle) AFM scan regions for the increasing growth temperature of AlGaN epilayers. The rms values of $5 \times 5 \mathrm{~m}^{2}$ and
$1 \mathrm{x} 1 \mu \mathrm{m}^{2}$ AFM scan areas for sample A, B and C are $0.61,0.35,0.22 \mathrm{~nm}$ and $0.30,0.23,0.19$, respectively. It is clearly seen from the Figure 5 that the growth temperature effects the rms 
roughness of the AlGaN surfaces so that when the growth temperature increases the surface getting smoother. It is again indicating that the more temperature the less roughness on the surface which demonstrates the reducing of dislocation density.

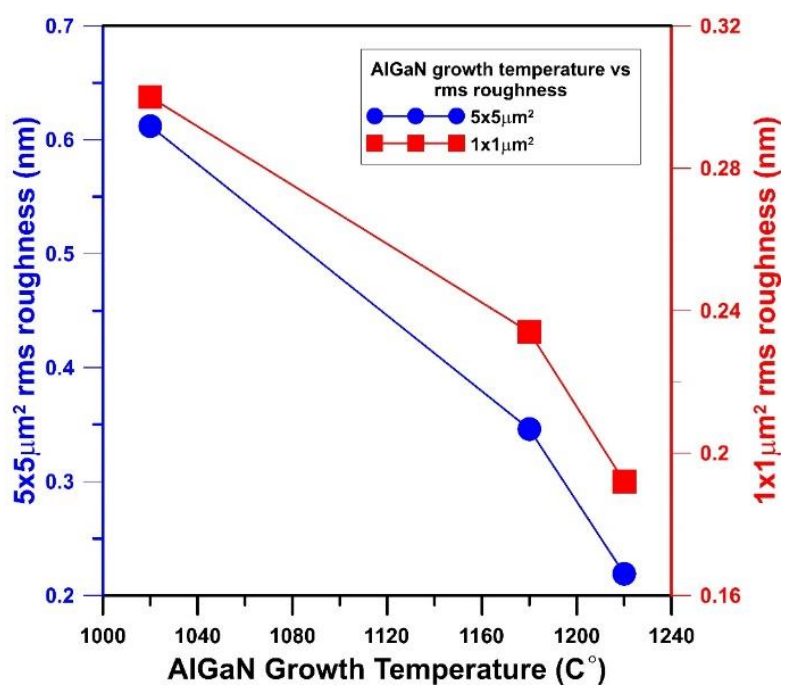

Figure 5. Rms values for $5 \times 5 \mu \mathrm{m}^{2}$ (red square) and $1 \mathrm{x} 1 \mu \mathrm{m}^{2}$ (blue circle) regions versus growth temperature of $\mathrm{AlGaN}$ epilayers.

\section{CONCLUSIONS}

In this paper, the crystalline quality and surface morphology of MOVPE grown AlGaN epilayers

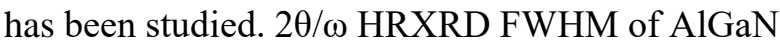
(0002) diffraction peaks and surface root mean square roughness variation were investigated by changing the growth temperature. It was shown that the growth temperature change from $1020^{\circ} \mathrm{C}$ to $1220{ }^{\circ} \mathrm{C}$ increased the $\mathrm{Al}$ content of $\mathrm{AlGaN}$ epilayers from $54.8 \%$ to $83.9 \%$. It was also shown that surface root mean square roughness values for $5 \times 5 \mu \mathrm{m}^{2}$ and $1 \times 1 \mu \mathrm{m}^{2}$ scan regions was improved from 0.61 to $0.22 \mathrm{~nm}$ and from $0.30 \mathrm{~nm}$ to $0.19 \mathrm{~nm}$, respectively.

\section{Acknowledgments}

This study is supported by TUBITAK under project Number 117F339. The authors acknowledge the usage of Nanophotonics Research and Application Center at Cumhuriyet University (CUNAM) facilities.

\section{REFERENCES}

[1]. Brunner F., Zettler J-T., Weyers M., Advanced in-situ control for III-nitride RF power device epitaxy, Semicond. Sci. Technol., 33 (2018) 045014.

[2]. Li K., Rakheja S., An analytic current-voltage model for quasi-ballistic III-nitride high electron mobility transistors, Journal of Applied Physics, 123 (2018) 184501.

[3]. Cordier Y., Comyn R., Frayssinet E., Khoury M., Lesecq M., Defrance N., De Jaeger J-C, Influence of AlN Growth Temperature on the Electrical Properties of Buffer Layers for GaN HEMTs on Silicon, Physica Status Solidi A, 215 (2018) 1700637.

[4]. Lee D., Lee J. W., Jang J., Shin I-S., Jin L., Park J. H., Kim J., Lee J., Noh H-S., Kim YI., Park Y., Lee G-D, Park Y., Kim J. K., Yoon E., Improved performance of AlGaN-based deep ultraviolet light-emitting diodes with nano-patterned AlN/sapphire substrates, Appl. Phys. Lett. 110 (2017), 191103.

[5]. Alias M. S., Tangi M., Holguin-Lerma J. A., Stegenburgs E., Alatawi A. A., Ashry I., Subedi R. C., Priante D., Shakfa M. K., Ng T. K., Ooi, B. S., Review of nanophotonics approaches using nanostructures and nanofabrication for III-nitrides ultravioletphotonic devices, J. Nanophoton. 12 (4) (2018), 043508.

[6]. Wang W., Li Y., Zheng Y., Yang Z., Lin Z., Chen X., Lu Z., Li G., Performance-improved vertical GaN-based light-emitting diodes on $\mathrm{Si}$ substrates through designing the epitaxial structure CrystEngComm, 20 (2018) 46854693.

[7]. Laws E. A.,, Environmental Toxicology: Selected Entries from the Encyclopedia of Sustainability Science and Technology, Springer Science \& Business Media, 2013.

[8]. Demir I., Robin Y., McClintock R., Elagoz S., Zekentes., Razeghi M., Direct growth of thick AlN layers on nanopatterned Si substrates by cantilever epitaxy, Phys. Status Solidi A 214 (4) (2017) 1600363.

[9]. Huang L., Li Y., Wang W., Li X., Zheng Y., Wang H., Zhang Z., Li G., Growth of high- 
quality AlN epitaxial film by optimizing the $\mathrm{Si}$ substrate surface, Applied Surface Science 435 (2018) 163-169.

[10].Li Y., Wang W., Li X., Huang L., Zheng Y., Chen X., Li G., Nucleation layer design for growth of a high-quality AlN epitaxial film on a $\mathrm{Si}(111)$ substrate, CrystEngComm, 20 (2018) 1483-1490.

[11].Tran B. T., Hirayama H., Growth and Fabrication of High External Quantum Efficiency AlGaN-Based Deep Ultraviolet Light-Emitting Diode Grown on Pattern Si Substrate, Scientific Reports 7 (2017) 12176.

[12].Dai Q., Zhang X., Liang Z., Yang G., Wu Z., Chen S., Zhao J., Meng C., Wang J., Cui Y., Effects of indium surfactant on growth and characteristics of (1122) plane AlGaN-based multiple quantum wells, Optical Materials Express, 8 (2018) 24-29.

[13].Yang W., Li J., Lin W., Li S., Chen H., Liu D., Yang X., Kang J., Control of two-dimensional growth of AlN and high Al-content AlGaNbased MQWs for deep-UV LEDs, AIP Advances 3 (2013), 052103.

[14].Demir I., Li H., Robin Y., McClintock R., Elagoz S., Razeghi M., Sandwich method to grow high quality AlN by MOCVD, Journal of Physics D: Applied Physics 51 (8) (2018) 085104.
[15].Shimanara Y., Miyake H., Hiramatsu K., Fukuyo F., Okada T., Takaoka H., Yoshida H., Growth of High-Quality Si-Doped AlGaN by Low-Pressure Metalorganic Vapor Phase Epitaxy, Japanese Journal of Applied Physics 50 (2011) 095502.

[16].Funato M., Banal R. G. Kawakami Y., Screw dislocation-induced growth spirals as emissive exciton localization centers in Alrich AlGaN/AlN quantum wells, AIP Advances 5 (2015) 117115.

[17].Wang C., Wang X., Hu G., Wang J., Li J., Influence of $\mathrm{Al}$ content on electrical and structural properties of Si-doped AlxGa1xN/GaN HEMT structures, Phys. Stat. Sol. (C) 3 (3) (2006) 486-489.

[18].Massabuau F. C. P., Rhode S. L., Horton M. K., Hanlon T. J. O., Kovacs A., Zielinski M. S., Kappers M. J., Borkowski R. E. D., Humphreys C. J., Oliver R. A., Dislocations in AlGaN: Core Structure, Atom Segregation, and Optical Properties, Nano Lett., 17 (2017) 4846-4852.

[19].Lee, H. P., Perozek J., Rosario L. D., Bayram C., Investigation of $\mathrm{AlGaN} / \mathrm{GaN}$ high electron mobility transistor structures on $200-\mathrm{mm}$ silicon (111) substrates employing different buffer layer configurations, Sci. Rep. 6, (2016) 37588. 